\title{
Assessing impact and sustainability of health, water, and sanitation interventions in Bolivia six years post-project
}

\author{
Clara Eder,${ }^{1}$ Janine Schooley, ${ }^{1}$ Judith Fullerton, ${ }^{2}$ and Jose Murguia ${ }^{3}$
}

Suggested citation

Eder C, Schooley J, Fullerton J, Murguia J. Assessing impact and sustainability of health, water, and sanitation interventions in Bolivia six years post-project. Rev Panam Salud Publica. 2012;32(1):43-8.

\begin{abstract}
Objective. To assess the impact and sustainability of health, water, and sanitation interventions in Bolivia six years post-project.

Methods. A mixed-method (qualitative-quantitative) study was conducted in 14 rural intervention and control communities in Bolivia in November 2008, six years after the completion of interventions designed to improve knowledge and practices related to maternal and child health and nutrition, community water systems, and household water and sanitation facilities. The degree to which participants had sustained the community and household practices promoted by the interventions was a particular focus. Community site visits were made to evaluate the status (functional condition) and sustainability (state of maintenance and repair) of community and household water and sanitation infrastructure. Key informant interviews and focus group discussions were conducted to assess knowledge and practices, and perceptions about the value of the interventions to the community.

Results. Six years post-project, participants remained committed to sustaining the practices promoted in the interventions. The average rating for the functional condition of community water systems was $42 \%$ higher than the average rating in control communities. In addition, more than two-thirds of households continued to practice selected maternal and child health behaviors promoted by the interventions (compared to less than half of the households in the control communities). Communities that received integrated investments (development and health) seemed to sustain the practices promoted in the interventions better than communities that received assistance in only one of the two sectors.

Conclusions. Infrastructure for community water systems and household water and sanitation facilities was better built and maintained, and selected maternal and child health behaviors practiced more frequently, in intervention communities versus control communities.
\end{abstract}

Key words Water supply; sanitation; house sanitation; community development; health education; technical cooperation; community networks; infrastructure projects; Bolivia.

Bolivia, which has a population of 10 million people, is one of the poorest and least-developed countries in Latin Amer-

1 Project Concern International, San Diego, California, United States of America. Send correspondence to: Clara Eder, ceder@pciglobal.org

2 Independent Consultant, San Diego, California, United States of America.

3 Project Concern International-Bolivia, La Paz, Bolivia. ica. Although the national language is Spanish, many people in rural areas speak the indigenous languages of Quechua or Aymara. Globally the country ranks 107th (out of 170) for average per capita income, which was estimated in 2009 as US \$911 overall (1) but may be as low as US \$150 in rural areas, illustrating the economic disparities within the country (2). About $60 \%$ of the population is thought to live below the poverty line (3). Bolivia ranks 95th (out of 169) on the World Bank Human Development Index and is categorized as a country at the medium level of human development (4).

Almost two-thirds of the Bolivian people work as subsistence farmers, miners, and traders. The country's economy has 
historically demonstrated a single-commodity focus, including-over timesilver, tin, and coca. While agricultural growth is intricately linked to poverty reduction $(5,6)$, political instability and difficult topography have constrained efforts to modernize the agricultural sector. Similarly, relatively low population growth (2.1\% over the period 1990-2007) coupled with low life expectancy (age 65 in 2007) and high incidence of disease has kept the labor supply in flux and prevented industries from flourishing. The mining industry-especially the extraction of natural gas, zinc, silver, and tin-currently dominates Bolivia's export economy (3).

In the area of water and sanitation, there is wide range in access to and use of services by type of residence. In 2006, while the overall proportion of families in Bolivia with access to improved drinking water sources was cited as $86 \%$, there was a wide variance between urban and rural populations (96\% versus $69 \%$ respectively). Disparities by type of residence were even greater for the proportion of the population that used improved sanitation facilities, which is $43 \%$ overall but ranges from $54 \%$ in urban areas to only $22 \%$ in rural areas (2). Access to sources of potable water and environmental sanitation has been clearly identified as a fundamental influence on community health, particularly the prevention of diarrhea in children (7). A variety of methods for improving drinking water have been tested for adaptability to various geographic settings in Bolivia. Studies indicate that the use of ceramic water filters (8) and solar disinfection of drinking water (9-12) are highly suitable approaches, although other research highlights the risk that water that is rendered potable using these and other methods can be reinfected at the point of contact for household use (13).

In the area of maternal and child health, Bolivia ranks favorably for various indicators. The national under-5 mortality rate was 51.2/1000 in 2009 (14), ranking Bolivia at 61 out of 262 countries for this health measure (15). In 2010, the estimated national infant mortality rate was 43.4/1 000 (3), which is relatively high when compared to aggregate data from other South American countries (16). The country also has a favorable rate of exclusive breast-feeding (60.4\%) (14). This may be partially attributable to international assistance that has helped the country find effective ways to promote timely initiation of breast-feeding, including exclusive breast-feeding $(17,18)$. Antenatal care attendance is moderate, with $58 \%$ of women making at least four visits, and two-thirds delivering with a skilled attendant. However, the upper-limit maternal mortality ratio is cited as relatively high (180, with an uncertainty interval of 110-284) (19).

Several international agencies have focused on Bolivian child nutrition (20), with some evidence of success. Chronic malnutrition and stunting among children have been attributed in part to the influence of ethnicity on dietary intake of protein and micronutrients, and to the economic and development factors that affect food security (21).

From 1997 to 2002, Project Concern International (PCI) and its partners (municipal governments, non-governmental organizations [NGOs], and local communities) implemented interventions in 14 rural communities in Bolivia in the areas of agricultural productivity, rural infrastructure, maternal and child health and nutrition, and community/ household water and sanitation as part of a US \$26 million Development Assistance Program (DAP) funded by the U.S. Agency for International Development (USAID) Title II program. PCI is a U.S.-based, international NGO that has worked with vulnerable households and other stakeholders throughout Bolivia to build capacity and address priority health and development needs at the community level since 1980. The overall goal of the DAP was to reduce high levels of food insecurity and poverty in select rural municipalities of Cochabamba and Northern Potosí.

The DAP strategies that focused on improving the health and nutritional status of vulnerable women and children utilized the incentive model for food distribution ("food for work"). This model calls for the use of food as compensation for the time family members spend participating in education, health, and food security activities. In some communities, these interventions were complemented by USAID Food for Education activities (the provision of food for schools integrated with other activities aimed at improving the quality of education) through funding from the U.S. Department of Agriculture (USDA). Community members participated in the distribution of school breakfasts, the engagement of parents in school feeding activities, and the establishment of school gardens. The activities were intended to improve nutrition, education, and overall health status among participating rural school-aged children. In addition, resources were provided to impoverished communities in several municipalities to improve their homes and living conditions and thus mitigate the risk of Chagas disease (22). Intercultural maternal and child health and nutrition activities were used to bridge the gap between traditional indigenous health practices and modern medicine. Community-based health education sessions emphasizing health-promoting behaviors that could be adopted at the household level were also offered. Discussions focused on the importance of identifying a source of primary health care services for all household members (23), particularly pregnant women and children under age 2 .

Community health promoters were trained to provide other residents of their communities with one-on-one and group-based health and nutrition education (e.g., antenatal care, breast-feeding, childhood immunization, and use of health facilities and services) that encouraged them to take positive actions for the health and well-being of their families and communities.

The DAP water and sanitation interventions promoted community- and household-level implementation and oversight of water and sanitation systems and facilities by utilizing a learningby-doing methodology that resulted in the construction of adequate infrastructure for good-quality community water supply (intake systems, collection and storage tanks, and distribution networks) and household water and sanitation (house pipe connections to public water sources, and household latrines) in a relatively short period of time. Training and technical assistance was provided to local operators and community leaders who then helped guide others in system operation and maintenance. This methodology enabled communities and households to build their own systems and assume responsibility for ongoing administrative and maintenance duties. Community-led committees formed during the interventions (focusing on irrigation, and water and sanitation) were instrumental in sustaining improvements in these systems. 
Six years after the completion of the DAP, as part of its commitment to monitoring and evaluation follow-up, PCI returned to the DAP-assisted communities to conduct a post-project review. Postproject reviews measure indicators of change to assess programmatic impact and sustainability of results. This type of research is limited in the literature, even though it is not time-bound and has proven extremely useful in improving future project performance. The PCI assessment of the DAP interventions in Bolivia helps to fill this gap. This report describes the assessment of the health, water, and sanitation components. The goal of the assessment was to assess the impact and sustainability of the DAP interventions on knowledge and practices related to maternal and child health and nutrition, community water supply, and household water and sanitation six years post-project.

\section{MATERIAL AND METHODS}

\section{Study design and ethics}

The study combined the qualitative methodology of a rapid post-project assessment with the quantitative methodology used in randomized controlled community comparisons, similar to the approach used in the DAP baseline, midterm, and final evaluations.

Because the study was conducted as a monitoring and evaluation exercise rather than independent research, approval for implementation was requested and received from the project stakeholders (administrative authorities in the regions and communities where the interventions were carried out) rather than an institutional review board. Nevertheless, all study methods were designed in accord with generally accepted principles of research ethics for the protection of human subjects. Therefore, data were collected only from adults who verbally consented to participate in the interview or focus group. Community participants were provided with information on the nature and expectations of the study, including the potential risks and benefits of participation, and their right to refuse or withdraw from the study without consequences. Public officials were interviewed in their official capacity on issues within the public domain. Data were coded and recorded in such a manner that the identity of participating individuals could not be established.
Dissemination activities were planned to convey the results of the study to project stakeholders and participants in the intervention communities.

\section{Sampling and interviews}

The sample included a total of 14 communities in two of Bolivia's nine departments (Potosí and Cochabamba). In each of the two departments, six communities served as observation sites ("intervention communities") and one community served as a control.

Interviews were conducted with 136 individual project beneficiaries (e.g., mothers, farmers, community leaders, health promoters, agricultural producers, and members of the irrigation and water and sanitation committees). Twenty focus group interviews were conducted, with an average of five participants per group. Additional interviews were carried out with health center personnel and government representatives. Overall, qualitative data were obtained from more than 300 members of the intervention and control communities. In addition, 16 PCI staff members were interviewed. Many of these staff members had been instrumental in the original design and early implementation of project activities, so their perspectives about the more effective elements of the project were particularly informative.

The sampling frame for the quantitative data was based on a census figure of 555 households. A 90\% confidence interval was calculated, resulting in a targeted sample of 91 households, of which only 66 households $(73 \%)$ were contactable. All 66 households voluntarily agreed to participate. The assessment was conducted in November 2008, six years after the completion of the DAP interventions in all communities.

\section{Instruments}

The study team developed 15 different guides, designed specifically for the assessment, for use among members of the community, key informants, and focus group participants. The guides, which described the main messages of the DAP health, water, and sanitation interventions, were pilot-tested in the intervention communities, revised accordingly, and translated by native speakers into the vernacular form of Spanish common to the region. Translators were used when necessary for communication in local indigenous languages. A set of checklists and rating scales was also developed for use in documenting the results of observations about infrastructure status and sustainability made at the community and household level.

\section{Procedures}

The study period consisted of four weeks of fieldwork preceded by several weeks of logistical planning and a two-day orientation meeting with PCI's Bolivia team members in La Paz. The fieldwork consisted of interviews, focus group discussions, and household and community site visits to evaluate water and sanitation infrastructure. The work was carried out by two six-member teams who shared responsibility for visiting the 14 study communities (12 observation sites and 2 controls). A total of 16 PCI staff members-14 from the Bolivia national office and two from U.S. headquartersparticipated in the field component. The overall research effort was underpinned by additional support from PCI staff in La Paz, Oruro, and Cochabamba.

\section{RESULTS}

The results of this assessment indicate that the 240525 people estimated to benefit from various activities conducted under the DAP continue to benefit from the interventions in varying degrees. Overall, selected maternal and child health behaviors were practiced more frequently and infrastructure for community water systems and household water and sanitation facilities was better built and maintained in the DAP intervention communities versus the control communities.

Communities that received integrated investments (development and health) seemed to sustain the practices promoted in the interventions better than communities that received assistance in only one of the two sectors.

\section{Health and nutrition}

Based on various maternal and child health indicators, the intervention communities showed high levels of sustainability of certain behaviors promoted in the DAP health interventions, although there was some erosion in hygiene and sanitation practices as well as latrine maintenance. 
Figure 1 illustrates the percentage of households in the intervention communities that were still practicing selected health behaviors advocated by the DAP six years after its completion. More than two-thirds $(80 \%)$ of the intervention households were still receiving and documenting maternal and child health services. These positive behaviors were also being extended to children born after the completion of the DAP. For example, more than two-thirds of infants born during the six-year post-project period had health cards (only 17\% less than the rate among children who participated in the DAP). In addition, the vast majority $(>87 \%)$ of households in intervention communities were using soap or detergent for hand washing and personal hygiene, with a smaller proportion

FIGURE 1. Proportion (\%) of households still practicing selected behaviors promoted in maternal and child health intervention six years post-project, Cochabamba and Northern Potosí, Bolivia, November 2008

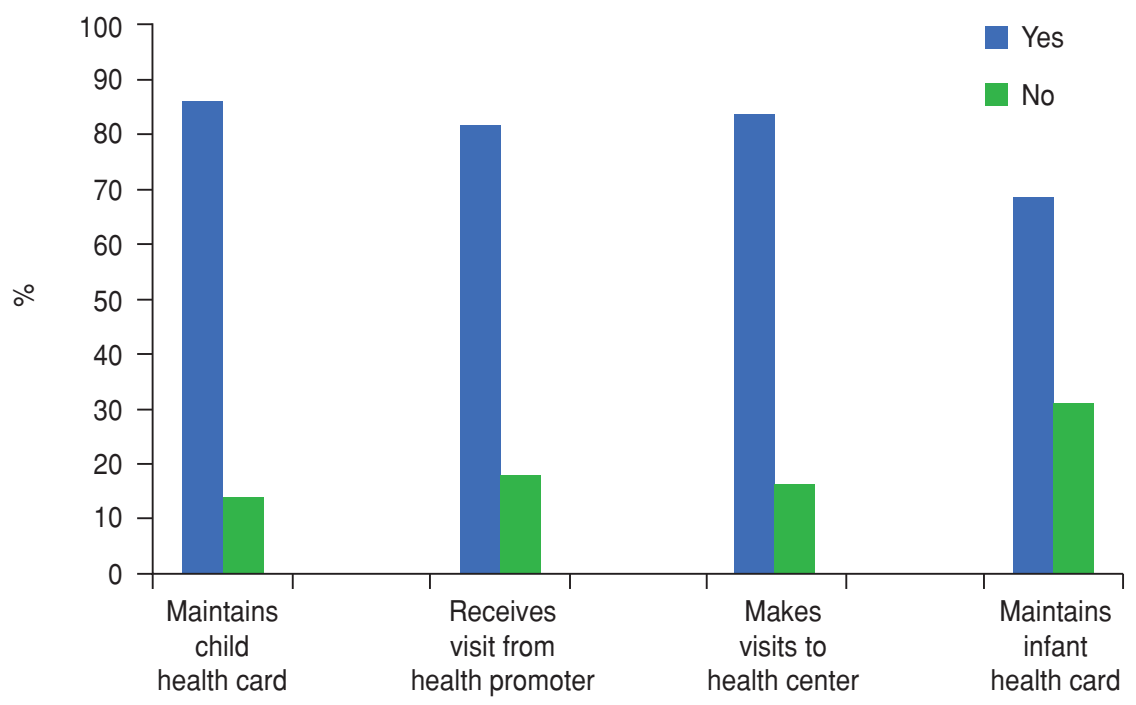

TABLE 1. Status (functional condition) and sustainability (state of maintenance and repair) of community and household water and sanitation (W\&S) infrastructure six years after project advocating improved W\&S practices: intervention versus control communities, Cochabamba and Northern Potosí, Bolivia, November 2008a

\begin{tabular}{|c|c|c|c|}
\hline Infrastructure & $\begin{array}{l}\text { Intervention } \\
\text { communities }\end{array}$ & $\begin{array}{c}\text { Control } \\
\text { communities }\end{array}$ & $\begin{array}{c}\text { Difference } \\
(\%)\end{array}$ \\
\hline \multicolumn{4}{|l|}{ Community water system } \\
\hline Status ${ }^{b}$ & 1.86 & 3.20 & 41.90 \\
\hline Sustainability & 1.87 & 2.67 & 30.00 \\
\hline \multicolumn{4}{|c|}{ Household water and sanitation facilities } \\
\hline Status ${ }^{c}$ & 2.40 & 3.44 & 30.20 \\
\hline Sustainability & 2.60 & 3.74 & 30.50 \\
\hline \multicolumn{4}{|c|}{$\begin{array}{l}\text { a Rated on a scale of } 1 \text { ("good") to } 4 \text { ("poor") by water and sanitation engineers employed by primary implementing organization } \\
\text { (Project Concern International, San Diego, CA, USA). } \\
\text { b Functional condition of intake systems, collection and storage tanks, distribution networks, and pipes; sufficiency of wate } \\
\text { quantity; water quality. } \\
\text { c Functional condition of water taps, collection tanks, valve chambers, and overflow channels; use and maintenance of latrines } \\
\text { condition of septic tanks. }\end{array}$} \\
\hline
\end{tabular}

committees whose function was to ensure that community irrigation and water systems and household water and sanitation facilities were built, operated, and maintained properly. Water committee responsibilities also included the determination and processing of fees for service and the establishment of usage protocols. At six years post-project, 62 respondents (about $98 \%$ of those who answered the question) reported that these water committees still functioned.

Table 1 shows the ratings for status (functional condition) and sustainability (state of repair and maintenance) of community water and household water and sanitation infrastructure in intervention and control communities six years after project completion, based on a scale of 1 ("good") to 4 ("poor") created and applied by water and sanitation engineers hired by PCI. The rating criteria for community water infrastructure included: condition of intake systems, collection and storage tanks, distribution networks, and pipes; sufficiency of water quantity; and water quality. The rating criteria for household water and sanitation infrastructure included: condition of water taps, collection tanks, valve chambers, and overflow channels; use and maintenance of latrines; and condition of septic tanks. Overall, the average rating for status of community water system infrastructure in the intervention communities was $42 \%$ percent higher than the average rating for status of infrastructure in the control communities. In addition, intervention communities were $30 \%$ more likely to have sustained the quality of these systems and facilities over time through proper maintenance and repair.

A similar assessment, of both water and sanitation infrastructure, was made at the household level. Households in intervention communities were approximately $30 \%$ more likely to be rated "good to very good" or "satisfactory" for status of water infrastructure and septic tanks, and both status and use of latrines, compared to households in control communities.

A comparison of community and household systems in both intervention and control communities suggests that water systems were well maintained at the community (macro) level but less well maintained at the household (micro) level. The low sample size of the control group $(n=2)$ precluded testing statistical differences between the intervention and control communities for this variable. 
Maintenance of household latrines was less successful over the six-year post-project period. While 48 households (about 73\%) reported owning latrines, on-site visual inspection of household latrines only identified $33(50 \%)$ that were still in use for the intended purpose. (Several latrines observed by the evaluation team were being used to store firewood or were not being used at all.)

\section{DISCUSSION}

The results of this study concur with evidence from previous studies. For example, a 2006 review of water provision and management strategies in Latin American countries found that the community-managed approaches facilitated in the DAP favored greater access to water among those of lower socioeconomic status (24), and a more recent study conducted in Bolivia found a positive correlation between motivation to adopt new water treatment habits and prior engagement in sanitary hygiene activities similar to the interventions used in the DAP (25).

A distinct strength of the current assessment was the fact that it was not funded by the sponsor of the DAP interventions and therefore did not present a conflict of interest (e.g., the participants knew USAID was not funding the assessment so they had no expectations of a potential benefit in terms of additional funding or program extensions-or apprehensions about program funding being withdrawn-based on the results).

This assessment also had several limitations. First, the census data used for sampling did not accurately reflect the number of households in the communities that were studied. This discrepancy affected the sampling distribution and resulted in a final sample size of 66 (73\% of the original intended sample of 91 households), making it difficult to apply the results widely. Nevertheless, meaningful comparisons can be made for selected variables, providing useful data for the participating communities. Another limitation was the

1. NationMaster.com. Economy statistics. Gross national income (per capita) (most recent) by country. Woolwich, Australia: Rapid Intelligence; c2011. Available from: http://www. nationmaster.com/graph/eco_gro_nat_inceconomy-gross-national-income Accessed 15 May 2010. fact that, as expected, many community residents included in the sample did not have detailed recollections of the interventions six years after project completion. This underscored the importance of waiting long enough post-project to allow for meaningful data on sustainability without waiting too long to collect substantive data from intervention participants, given community migration patterns and the fact that those in administrative positions are highly mobile in their careers. Finally, it was difficult to quantify the community benefits observed in the assessment because they were not necessarily directly or solely attributable to the DAP. To help clarify the correlation between the DAP interventions and the observed changes in knowledge and practices, efforts were made to document other, similar interventions carried out in the same communities before and after the project. Based on these efforts, it was determined that the positive changes in health, nutritional, and educational status identified in the assessment had many additional sources of influence during the six-year post-project period (2002-2008), including development and health programs conducted by other NGOs. For example, 63 respondents (about $40 \%$ of those who answered the question) said they had participated in other NGOs' health programs since the completion of the DAP. Nevertheless, each of the health promoters, teachers, and leaders interviewed (a total of 20) who had been engaged by other NGOs for similar activities attributed positive health and development changes in their communities specifically to the DAP. In addition, the inclusion of communities that did not participate in the DAP but had been included in interventions from other NGOs helped to control this source of bias.

\section{Conclusions}

Six years post-project, the DAP intervention participants remained committed to sustaining the practices promoted by the project. This was reflected in the fact that 1) several maternal and child health

\section{REFERENCES}

2. United Nations Children's Fund. Bolivia, Plurinational State of: statistics. New York: UNICEF; c2011. Available from: www.uni cef.org/infobycountry/bolivia_statistics.html Accessed 10 February 2011.

3. Central Intelligence Agency (US). Bolivia. Available from: https://www.cia.gov/library/ and nutrition behaviors learned in the interventions were still being practiced by households, and 2) there was a marked difference between the water and sanitation infrastructure status and sustainability ratings for the intervention communities and those for the control communities.

Post-project sustainability studies like the current assessment provide the opportunity to move beyond typical donorrequired monitoring and evaluation activities, generating more evidence of program impact and long-term sustainability as well as feasibility and value. These types of results provide useful lessons for programming and help guide future project design.

Acknowledgments. The authors thank members of the 14 communities in Bolivia who participated in this study, and acknowledge the invaluable assistance of the evaluation team in Bolivia (Alejandra Villafuerte, Guadalupe Tola, Janet Carrasco, Nicolás Copa, and Porfirio Choque); the monitoring and evaluation officer (Elizabeth Abastoflor); and PCI support staff in Cochabamba, Oruro, and La Paz. They also thank Charles Sturtevant, for his translation and field insights; the staff of PCI's International Office (San Diego, CA, USA); and Dr. Hassan Sachedina, who contributed to the design and analysis of this study. In addition, the authors offer special thanks to the Richard Taylor Global Impact Fund for its support of this important, pioneering effort in assessing post-project sustainability.

Disclaimer/conflict of interest. The findings and conclusions in this report are those of the authors and do not necessarily represent the position of the private funding agency that supported this assessment. The authors are current (CE, JS, JM) or former (JF) employees of PCI, the NGO that designed and implemented the Development Assistance Program (DAP) evaluated in this study, and conducted the post-project assessment. The authors have no financial interest in the publication of the results of this assessment. publications / the-world-factbook/geos/bl. html Accessed 10 February 2011.

4. United Nations Development Programme. Human Development Index: statistical annex. Table 1: Human Development Index and its components. Available from: http:/ / hdr.undp.org/en/media/HDR_2010_EN_ 
Table1_reprint.pdf Accessed 10 February 2011.

5. Xavier I, Lin L, Thirtle C, Wiggins S. Agricultural productivity growth and poverty alleviation. Dev Pol Rev. 2001;19(4):449-66.

6. Pfeiffer LM. Agricultural productivity growth in the Andean Community. Am J Agr. Econ. 2003;85(5):1335-41.

7. Tornheim JA, Morland KB, Landrigan PJ, Cifuentes E. Water privatization, water source, and pediatric diarrhea in Bolivia: epidemiologic analysis of a social experiment. Int J Occup Environ Health. 2009;15(3):241-8.

8. Clasen T, Brown J, Collin S. Preventing diarrhea with household ceramic water filters: assessment of a pilot project in Bolivia. Int J Environ Health Res. 2006;16(3):231-9.

9. Mäusezahl D, Christen A, Pacheco GD, Tellez FA, Irarte M, Zapata ME, et al. Solar drinking water disinfection (SODIS) to reduce childhood diarrhoea in rural Bolivia: a cluster-randomized, controlled trial. PLoS Med. 2006;6(8):e1000125.

10. Moser S, Mosler HJ. Differences in influence patterns between groups predicting the adoption of a solar disinfection technology for drinking water in Bolivia. Soc Sci Med. 2008; 67(4):497-504.

11. Heri S, Mosler HJ. Factors affecting the diffusion of solar water disinfection: a field study in Bolivia. Health Educ Behav. 2008;35(4):541-60.

12. Tamas A, Tobias R, Mosler HJ. Promotion of solar water disinfection: comparing the effectiveness of different strategies in a longitu- dinal field study in Bolivia. Health Commun. 2009;24(8):711-22.

13. RufenerS,MäusezahlD, Mosler HJ, Weingartner R. Quality of drinking-water at source and point-of-consumption-drinking cup as a high potential recontamination risk: a field study in Bolivia. J Health Popul Nutr. 2010;28(1):34-41.

14. World Bank. HNPStats: Country at a glance [Bolivia]. Washington: World Bank; c2011. Available from: http://go.worldbank.org/ YB2ATM3HY0. Accessed 10 February 2011.

15. United Nations Population Fund. State of world population 2010. New York: UNFPA; c2011. Available from: http://www.unfpa. org/swp/2010/web/en/index.shtml Accessed 15 October 2011.

16. United Nations Children's Fund. The state of the world's children 2009. New York: UNICEF; c2011. Available from: http://www.unicef. org/sowc09/ Accessed 15 October 2011.

17. Quinn VJ, Guyon AB, Schubert JW, StoneJiménez M, Hainsworth MD, Martin LH. Improving breastfeeding practices on a broad scale at the community level: success stories from Africa and Latin America. J Hum Lact. 2005;21(3):345-54

18. Baker EJ, Sanei LC, Franklin N. Early initiation of and exclusive breastfeeding in largescale community-based programmes in Bolivia and Madagascar. J Health Popul Nutr. 2006;24(4):530-9.

19. Hogan MC, Foreman KJ, Naghavi M, Ahn SY, Wang M, Makela SM, et al. Maternal mortality for 181 countries, 1980-2008: a systematic analysis of progress towards Millennium Development Goal 5. Lancet. 2010;375(9726):1609-23.

20. Hoerée TF, Kolsteren PW, Sejas EV, Ventura $\mathrm{AF}$. The role of curative first-line health services in enhancing screening and rehabilitation of mild-to-moderate malnutrition: results of a pilot project in Bolivia. J Health Popul Nutr. 2005;23(2):200-1.

21. Larrea C, Freire W. Social inequality and child malnutrition in four Andean countries. Rev Panam Salud Publica. 2002;11(5-6):356-64.

22. Cortez MR, Monteiro FA, Noireau F. New insights on the spread of Traitoma infestans from Bolivia-implications for Chagas disease emergence in the southern cone. Infect Genet Evol. 2010;10(2):350-3. Epub 2010 Jan 7

23. Caruso B, Stephenson R, Leon JS. Maternal behavior and experience, care access, and agency as determinants of child diarrhea in Bolivia. Rev Panam Salud Publica. 2010;28(6): 429-39.

24. Mulreany J, Calikoglu S, Ruiz S, Sapsin JW. Water privatization and public health in Latin America. Rev Panam Salud Publica. 2006;19(1):23-32.

25. Christen A, Pacheo G, Hattendorf J, Arnold $B$, Cervallos M, Indergand S, et al. Factors associated with compliance among users of solar water disinfection in rural Bolivia. BMC Public Health. 2011;11(1):210.

Manuscript received on 11 July 2011. Revised version accepted for publication on 20 December 2011.

RESUMEN Objetivo. Evaluar la repercusión y la sostenibilidad de las intervenciones relacionadas con la salud, el abastecimiento de agua y el saneamiento en Bolivia seis años después de la realización del proyecto.

\section{Evaluación de la repercusión y la sostenibilidad a seis años de las intervenciones relacionadas con salud, agua y saneamiento en Bolivia}

Métodos. Se llevó a cabo un estudio de metodología mixta (cualitativa y cuantitativa) en 12 comunidades rurales donde se efectuó la intervención y 2 de control en Bolivia en noviembre del 2008, seis años después de la finalización de las intervenciones enfocadas a mejorar el conocimiento y las prácticas relacionadas con la salud y la nutrición maternoinfantil, los sistemas de abastecimiento de agua comunitarios y las instalaciones de abastecimiento de agua y saneamiento domiciliarias. Se estudió, en particular, el grado en el cual los participantes continuaban realizando las prácticas domiciliarias y comunitarias promovidas por las intervenciones. Se efectuaron visitas a sitios de la comunidad para evaluar el estado (condición funcional) y la sostenibilidad (estado de mantenimiento y reparación) de la infraestructura de abastecimiento de agua y saneamiento domiciliaria y comunitaria. Se llevaron a cabo entrevistas a informantes clave y análisis basados en grupos de discusión para evaluar el conocimiento, las prácticas y las percepciones acerca del valor de las intervenciones comunitarias. Resultados. Seis años después del proyecto, los participantes continuaban llevando a cabo las prácticas promovidas en las intervenciones. La calificación promedio para la condición funcional de los sistemas de abastecimiento de agua comunitarios fue $42 \%$ más alta que la calificación promedio en las comunidades de control. Además, en más de dos terceras partes de los hogares se seguían poniendo en práctica ciertos hábitos relacionados con la salud maternoinfantil promovidos en las intervenciones (en comparación con menos de la mitad de los hogares en las comunidades de control). Las comunidades que recibieron inversiones integradas (desarrollo y salud) parecían conservar las prácticas promovidas en las intervenciones en mayor medida que las comunidades que recibieron ayuda solo en uno de los dos sectores.

Conclusiones. La infraestructura de los sistemas de abastecimiento de agua comunitarios y las instalaciones domiciliarias de abastecimiento de agua y saneamiento estaban mejor construidas y mantenidas, y ciertos hábitos de salud maternoinfantil se ponían en práctica con mayor frecuencia, en las comunidades de la intervención en comparación con las comunidades de control.

Palabras clave

Abastecimiento de agua; saneamiento; saneamiento de la vivienda; desarrollo de la comunidad; educación en salud; cooperación técnica; redes comunitarias; proyectos de infraestructura; Bolivia. 